\section{Chemical Composition and Antibacterial Activity of the Essential Oil from Chinese Wild Ledum palustre L. on Vibrio Parahaemolyticus}

\author{
Liangliang Zhang ${ }^{1,2 *}$, Yongmei Wang ${ }^{2}$, Man $\mathrm{Xu}^{2}$, Xinyu $\mathrm{Hu}^{1,2}$ \\ ${ }^{1}$ Jiangsu Province Biomass Energy and Materials Laboratory, Nanjing 210042, China \\ ${ }^{2}$ Institute of Chemical Industry of Forest Products, CAF, Nanjing 210042, China
}

"Corresponding author: Liangliang Zhang, Jiangsu Province Biomass Energy and Materials Laboratory, Nanjing 210042, China; Tel: +86 25 85482463; Fax: +86 25 85482463; E-mail: zhl120086@163.com

\begin{abstract}
Objectives: To study the chemical components and antibacterial activity of essential oil from the aerial parts of Ledum palustre L. which were collected in Daxing'anling area of north-eastern China, in September 2014.

Methods: The subcritical fluid extraction technology (SFE) was used to isolate the essential oil from the plant's samples. Micro-SPE and GC-MS methods were applied to the identification of oil components and determination of their content in the essential oil. The antimicrobial activity of the essential oil was tested against the marine pathogen Vibrio parahaemolyticus at incubation of $37^{\circ} \mathrm{C}$.

Results: The yield of extract from the aerial parts was $5.31 \%$. The main constituents found were $\alpha$-thujenal (22.48\%), bicyclocompounds(18.72\%), $\beta$-phellandrene $(10.25 \%)$, benzene,1-methyl-3-(1-methylethyl)-(6.59\%), propanal,2-methyl-3-phenyl- $(4.01 \%)$ and $\beta$-terpineol (3.04\%). The essential oil from L.palustre at concentration of $5 \mathrm{~g} / \mathrm{L}$ can inhibit the growth of V.parahaemolyticus obviously.

Conclusion: This is the first report of an inhibitory activity of essential oil of L.palustre on the pandemic strain of V.parahaemolyticus in seawater.
\end{abstract}

Keywords: Ledum palustre L.; Essential oil; GC-MS; Vibrio parahaemolyticus
Received Date: December 16, 2016

Accepted Date: January 29, 2017

Published Date: February 03, 2017

Citation: Zhang, L., et al. Chemical Composition and Antibacterial Activity of the Essential Oil from Chinese Wild Ledum palustre L. on Vibrio Parahaemolyticus. (2017) Int J Food Nutr Sci 4(1): 8- 12.

DOI: $10.15436 / 2377-0619.17 .1270$

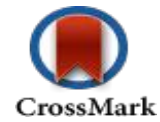

\section{Introduction}

Leum palustre $L$. also known as wild rosemary or marsh tea, is an evergreen low shrub growing wild in northern China and America, northern and central Europe. The plant grows in peaty soils, shrubby areas, moss and lichen tundra. It's leaves and flowers have a strong smell causing headache in some people. All parts of the plant contain poisonous terpenes that affect the central nervous system, causing aggressive behaviour. L. palustreis widely used in folk medicine and homoeopathy for the treatment of rheumatism, arthritis, and insect bite ${ }^{[1]}$.

The expectorant and antitussive effect of the marsh tea is due to the ledol contained in the plant's essential oil ${ }^{[1]}$. The composition of the essential oil from L.palustre varies considerably with habitat ${ }^{[2,3]}$. The major components present in the essential oil of L.palustre are $(+)-$ ledol $^{[4]},(-)$-palustrol ${ }^{[4,5]},(-)$ -cyclocolorenone ${ }^{[4]}$, myrcene, $p$-cymene and limonene ${ }^{[4,6]}$. Ledol was isolated first time from L. palustre in $1948^{[7]}$; cyclocolorenone thirty years later ${ }^{[8]}$. Isolation of volatile compounds from the plants by the sub-critical fluid extraction technology allowed to obtain more components which could not be found by conventional methods (steam distillation, Soxhlet extraction) ${ }^{[9]}$.

Subcritical fluid extraction (SFE), also called pressurized low-polarity fluid extraction, is one of the most popular techniques which can overcome the defects of the conventional organic solvent extraction and expeller pressing methods. It is an excellent extraction that has numerous advantages such as lower operating temperature and pressures, shorter extraction time, environmental compatibility, good selectivity, one step from the extraction to the separation and avoidance of residual solvents ${ }^{[10,11]}$. Different subcritical fluids have been used in SFE, but n-butane is used as the subcritical fluid mainly because it needs lower critical pressures and temperatures, and it has excellent dissolving power for lipophilic compound. Also this extract 
is a low boiling point, inexpensive, colourless, and clean solvent that leaves no solvent residue in the product. Isolation of volatile compounds from the plants by the SFE allowed to obtain more components which could not be found by conventional methods (steam distillation, Soxhlet extraction) $)^{[9]}$.

Vibrio parahaemolyticus is a halophilic gram-negative bacterium that is widely distributed in coastal waters worldwide and is associated with gastroenteritis, wound infections and septicaemia $^{[12]}$. V. Parahaemolyticus infections are frequently reported in coastal areas, apparently because of the high consumption of sea products and direct contact with estuarine waters ${ }^{[13]}$. Some efforts are needed to enhance the safety of seafood. Antimicrobial activities of herbs and essential oils have been well known for long time. Many studies reported the activities of herbs or essential oils to food borne pathogenic bacteria ${ }^{[14]}$. However, a few studies have investigated the effects of herbs and essential oils against marine pathogenic bacteria such as $V$. parahaemolyticus $^{[15]}$.

In the present work, the essential oil from the aerial parts of L.palustre L. growing wild in north-eastern China was extracted by SFE and its composition was determined by Micro-SPE and GC-MS methods. The inhibitory activity of the essential oil on a pandemic strain of $V$. Parahaemolyticus was also investigated.

\section{Materials and Methods}

\section{Plant materials}

The aerial parts of Chinese L. palustre were collected in Daxing'anling area of north-eastern China, in September 2014. The samples were dried at room temperature. Voucher specimens (No. CAF20140827001) were deposited at the Institute of Chemical Industry of Forest Products, Chinese Academy of Forestry.

\section{Subcritical fluid extraction}

Essential oil was isolated from the dried aerial parts of L. palustre $(2.37 \mathrm{~kg})$ by the subcritical fluid extraction technology (SFE) with butane (Nanjing Special Gas Factory Co., Ltd., $>99 \%$ ) as a solvent. The SFE process was performed according to Liu et $\mathrm{a}^{\left[{ }^{[11]}\right.}$ using the apparatus (Henan Subcritical Extraction Biological Technology, Co., Ltd, Anyang, China). A G445-5/613 pump (Beijing Huizhi Mechanical and Electrical Equipment Co., Ltd, China) with digital flow-rate and readouts was used to impel the n-butane extractant fluid through the system. The extraction capacity was $5 \mathrm{~L}$ and the maximum flow rate of the n-butane fluid was $80 \mathrm{~L} /$ hour.

The extraction experiment was carried out three times and the extraction yield was determined gravimetrically by the mass of extracted oil divided by the mass of L. palustre loaded in the extraction vessel, namely: The extraction yield $(\%)=$ (mass of extracted oil $/$ mass of dried material) $\times 100 \%$

\section{Chemical analysis}

The samples were analysed on a Varian Saturn 2000 System using a 1079 injector that had been fitted with the Chromato Probe kit. This kit allows the thermal desorption of small amounts of solids or liquids contained in quartz micro -vials ${ }^{[16]}$, or in our case the thermal desorption of the trapped volatiles. The adsorbent tube was loaded into the probe, which was then inserted into the modified GC injector.
The injector split vent was opened (1/20) and the injector heated to $40{ }^{\circ} \mathrm{C}$ to flush any air from the system. The split vent was closed after 2 minutes and the injector was heated at $200{ }^{\circ} \mathrm{C} /$ minute, and then held at $200{ }^{\circ} \mathrm{C}$ for 4.2 minutes, after which the split vent was, opened (1/10) and the injector cooled down.

A ZB-5 column ( $5 \%$ phenyl polysiloxane) was used for the analyses ( $60 \mathrm{~m}$ long, inner diameter $0.25 \mathrm{~mm}$, film thickness $0.25 \mu \mathrm{m}$, Phenomenex). Electronic flow control (EFC) was used to maintain a constant helium carrier gas flow of $1.8 \mathrm{~mL} /$ minute. The GC oven temperature was held for 7 minutes at $40^{\circ} \mathrm{C}$ then increased by $6^{\circ} \mathrm{C}$ per minute to $250{ }^{\circ} \mathrm{C}$ and held for 1 minute. The MS interface was $260{ }^{\circ} \mathrm{C}$ and the ion trap worked at 175 ${ }^{\circ} \mathrm{C}$. The mass spectra were taken at $70 \mathrm{eV}$ (in EI mode) with a scanning speed of 1 scan- 1 from $\mathrm{m} / \mathrm{z} 30$ to 350 . The GC-MS data were processed using the Saturn Software package 5.2.1. Component identification was carried out using the NIST 08 mass spectral data base (NIST algorithm).

Inhibitory activity of the essential oil on $\boldsymbol{V}$. parahaemolyticus: The extract of L.palustre was subjected for inhibitory activity against the test organism (V. parahaemolyticus, supplied by Prof. Yuanyue Li in Jimei University, Xiamen, China) by the modified disc method. Petri dishes containing $100 \mu \mathrm{L}$ of different concentrations of extract $(5 \mathrm{~g} / \mathrm{L}, 10 \mathrm{~g} / \mathrm{L}$ and $15 \mathrm{~g} / \mathrm{L})$ and Tryptic Soy Agar medium (TSA) prepared in sterilized diluted seawater $\left(10^{-1}, 10^{-2}\right.$ and $\left.10^{-3}\right)$ were labelled corresponding to the samples (T1-T3 and Control). Then $10 \mu \mathrm{L}$ of the test organism was taken from the $V$. parahaemolyticus stock (broth) and swabbed on $2 \%$ agar medium by using sterilized buds. The plates were then incubated at $37^{\circ} \mathrm{C}$ for 24 hours. The antimicrobial activity of the test extract was observed through the condition of bacterium growth on the plates.

\section{Results and Discussion}

The volatile metabolites of the aerial parts of $\mathrm{L}$. $\mathrm{Pa}$ lustre were extracted by sub-critical fluid extraction technology method and the yields of essential oil extract were $5.31 \% \pm$ $0.43 \%$. Peak identification and relative amounts of the various compounds present in the volatile fraction appear in Table 1. It shows the main constituents found; 56 compounds, comprising over $89 \%$ of the total essential oil yield, were identified. The chemical structures of the main components of the L.palustre essential oils were shown in Figure1.

Table 1: The main components of the L.palustre essential oil extract.

\begin{tabular}{|l|l|l|l|}
\hline No. & $\begin{array}{l}\text { Retention } \\
\text { time/min }\end{array}$ & Components & $\begin{array}{l}\text { Concen- } \\
\text { tration/\% }\end{array}$ \\
\hline 1 & 5.629 & 2-hexenal & 1.96 \\
\hline 2 & 7.188 & 2,4-hexadienal & 0.28 \\
\hline 3 & 7.539 & $\begin{array}{l}\text { bicyclo[3.1.0]hexane,4-meth- } \\
\text { yl-1-(1-methylethyl)- }\end{array}$ & 0.98 \\
\hline 4 & 7.679 & $\begin{array}{l}\text { bicyclo[3.1.0]hex-2-ene,2-methyl-5- } \\
\text { (1-methylethyl)- }\end{array}$ & 0.93 \\
\hline 5 & 8.152 & camphene & 0.64 \\
\hline 6 & 8.982 & $\beta$-phellandrene & 10.25 \\
\hline 7 & 9.467 & $\beta$-pinene & 0.12 \\
\hline 8 & 9.740 & 2,4-heptadienal & 0.19 \\
\hline
\end{tabular}


Antibacterial Activity from Chinese Wild Ledum palustre L. on Vibrio Parahaemolyticus

\begin{tabular}{|c|c|c|c|c|c|c|c|}
\hline 9 & 9.892 & $\alpha$-phellandrene & 0.56 & 35 & 19.684 & O-isopropylphenetole & 0.78 \\
\hline 10 & 10.286 & $(+)$-4-carene & 1.01 & 36 & 19.890 & allylidenecyclohexane & 0.33 \\
\hline 11 & 10.571 & $\begin{array}{l}\text { benzene,1-methyl-3-(1-methyleth- } \\
\text { yl)- }\end{array}$ & 6.59 & 37 & 20.084 & $\begin{array}{l}\text { 1,3,3-trimethyl-2-(2-methyl-cyclo- } \\
\text { propyl)-cyclohexene }\end{array}$ & 0.31 \\
\hline 12 & 10.923 & 1,3,6-octatriene,3,7-dimethyl- & 0.62 & 38 & 20.394 & $\alpha$-cubebene & 0.10 \\
\hline 13 & 11.620 & 3-carene & 1.70 & 39 & 20.848 & phenol,2-amino-5-methyl- & 0.57 \\
\hline 14 & 11.972 & $\beta$-terpineol & 3.04 & 40 & 21.151 & copaene & 0.04 \\
\hline \multirow{2}{*}{15} & \multirow{2}{*}{12.602} & \multirow{2}{*}{$\begin{array}{l}\text { cyclohexene, 1-methyl-4-(1-methyle- } \\
\text { thylidene)- }\end{array}$} & \multirow{2}{*}{0.52} & 41 & 22.382 & caryophyllene & 0.10 \\
\hline & & & & \multirow{2}{*}{42} & \multirow{2}{*}{23.213} & \multirow{2}{*}{$\begin{array}{l}\text { 1,6,10-dodecatriene,7,11-dimeth- } \\
\text { yl-3-methylene- }\end{array}$} & \multirow{2}{*}{0.12} \\
\hline \multirow{2}{*}{16} & \multirow{2}{*}{12.990} & \multirow{2}{*}{$\begin{array}{l}\text { cyclohexanol,1-methyl-4-(1-methy- } \\
\text { lethenyl)- }\end{array}$} & \multirow{2}{*}{2.50} & & & & \\
\hline & & & & \multirow{2}{*}{43} & \multirow{2}{*}{23.304} & \multirow{2}{*}{$\begin{array}{l}\text { 1,4,7-cycloundecatriene, } 1,5,9,9 \text {-te- } \\
\text { tramethyl- }\end{array}$} & \multirow{2}{*}{0.10} \\
\hline 17 & 13.306 & benzyl alcohol & 0.11 & & & & \\
\hline 18 & 13.894 & $\begin{array}{l}\text { bicyclo[3.1.0]hex-3-en-2-one,5-(1- } \\
\text { methylethyl)- }\end{array}$ & 10.37 & 44 & 23.553 & $\begin{array}{l}\text { 1H-cycloprop[e]azulene,decahy- } \\
\text { dro-1,1,7-trimethyl-4-methylene- }\end{array}$ & 2.96 \\
\hline \multirow{2}{*}{19} & \multirow{2}{*}{14.367} & \multirow{2}{*}{$\begin{array}{l}\text { bicyclo[3.1.1]heptan-3-ol,6,6-di- } \\
\text { methyl-2-methylene- }\end{array}$} & \multirow{2}{*}{1.08} & 45 & 24.189 & cycloheptasiloxane, tetradecamethy & 0.20 \\
\hline & & & & \multirow{3}{*}{46} & \multirow{3}{*}{24.844} & \multirow{3}{*}{$\begin{array}{l}\text { Naphthalene, } 1,2,4,4 \mathrm{a}, 5,6,8 \mathrm{a}-\mathrm{oc}- \\
\text { tahydro-7-methyl-4-methy- } \\
\text { lene-1-(1-methylethyl)- }\end{array}$} & \multirow{3}{*}{0.39} \\
\hline 20 & 14.639 & cyclooctanone & 0.42 & & & & \\
\hline \multirow{2}{*}{21} & \multirow{2}{*}{14.967} & \multirow{2}{*}{$\begin{array}{l}\text { bicyclo[3.1.0]hex- } \\
\text { an-2-one,5-(1-methylethyl)- }\end{array}$} & \multirow{2}{*}{3.66} & & & & \\
\hline & & & & \multirow{2}{*}{47} & 25.044 & Naphthalene, 1,2,3,5,6,8a-hexahy- & 0.19 \\
\hline 22 & 16.083 & $\alpha$-thujenal & 22.48 & & & dro-4,7-dimethyl-1-(1-methylethyl)- & \\
\hline 23 & 16246 & bicyclo[3.1.1]hept-2-ene-2-carbox- & 170 & 48 & 27.166 & ledol & 0.19 \\
\hline 25 & 10.240 & aldehyde,6,6-dimethyl- & 1.10 & 49 & 27.288 & 1,3,5,6-tetramethyladamantane & 0.86 \\
\hline 24 & 16.434 & 1-methylene-2-vinylcyclopentane & 0.15 & 50 & 28.634 & corymbolone & 0.63 \\
\hline 25 & 17.253 & phenol,4-(1-methylethyl)- & 0.24 & 51 & 30.295 & 1H-cycloprop[e]azulene, decahy- & 0.13 \\
\hline 26 & 17.447 & propanal,2-methyl-3-phenyl- & 4.01 & & & dro-1,1,4,7-tetramethyl- & \\
\hline 27 & 17.635 & ocimene & 0.07 & & & 2(3H)-naphthale- & \\
\hline 28 & 18.344 & 1,2,4,4-tetramethylcyclopentene & 0.26 & 52 & 30.816 & dro-4a,5-dimethyl-3-(1-methyle- & 0.26 \\
\hline 29 & 18.447 & 1,3-cyclohexadiene,5,6-dimethyl- & 0.26 & & & thylidene)- & \\
\hline 30 & 18.617 & Borny-1-acetate & 1.07 & 53 & 34.970 & n-hexadecanoic acid & 0.41 \\
\hline 31 & 18.914 & benzenemethanol,4-(1-methylethyl)- & 1.29 & 54 & 38.480 & 6-octadecenoic acid & 0.50 \\
\hline 32 & 19.096 & 5-isopropenyl-2-methylcyclo- & 0.20 & 55 & 38.844 & oleic acid & 0.11 \\
\hline & & pent-1-enecarboxaldehyd & & 56 & 41.239 & undecanoic acid propyl ester & 0.06 \\
\hline 33 & 19.260 & 5-octen-4-one, 7-methyl- & 0.52 & To- & & & \\
\hline 34 & 19.587 & cyclohexasiloxane, dodecamethyl- & 0.31 & tal & & & 09.45 \\
\hline
\end{tabular}

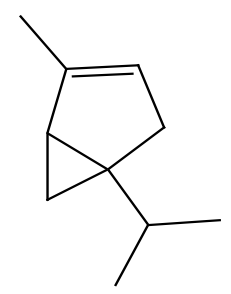

bicyclo[3.1.0]hex-2-ene, bicyclo[3.1.0]hex-2-ene, 2-methyl-5-(1-methylethyl)- 4-methyl-1-(1-methylethyl)- one,5-(1-methylethyl)-<smiles>CC1=CC=C(C(C)C)CC1</smiles>

1,3-cyclohexadiene, 1 methyl-4-(1-methylethyl)

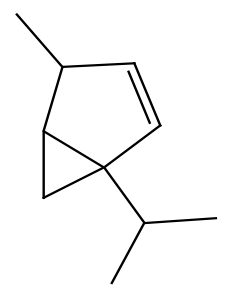<smiles>CC1=CCC(C(C)C)C=C1</smiles>

alpha-phellandrene

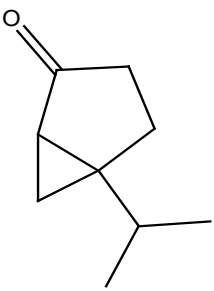<smiles>C=C1CC=C(C(C)C)CC1</smiles>

benzene, 1-methyl-4(1-methylethyl)-

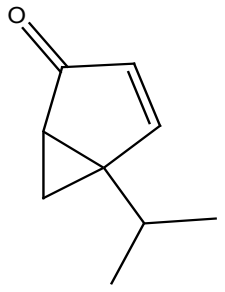

bicyclo[3.1.0]hex-3-en, 2-one,5-(1-methylethyl)-

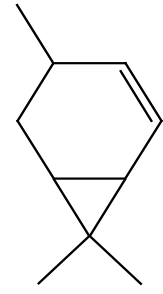

$(+)$-4-carene<smiles>C=C(C)C1CCC(C)(O)CC1</smiles>

cyclohexene,4-methylene- cis-beta-terpineol 1-(1-methylethyl)-

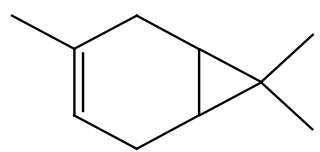

3-carene<smiles>CC1=CCC(C(C)C)=CC1</smiles>

1,4-cyclohexadiene, 1 methyl-4-(1-methylethyl)- 


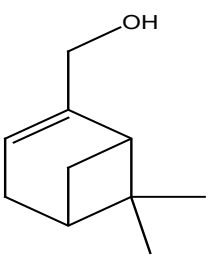

(-)-myrtenol

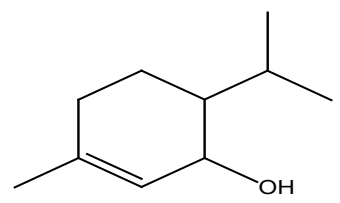

2-cyclohexen-1-ol,3-methyl-6(1-methylethyl)-,cis-<smiles>CC(C)c1ccc(O)cc1</smiles>

phenol,4-(1-methylethyl)-<smiles>CC(C)c1ccc(CO)cc1</smiles>

phenol,4-(1-methylethyl)- propanal,2-methyl-3-phenyl-<smiles>CC(C=O)Cc1ccccc1</smiles>

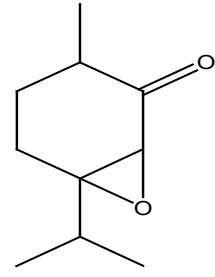

7-oxabicyclo[4.1.0]heptan-2-o 3-methyl-6-(1-methylethyl)-

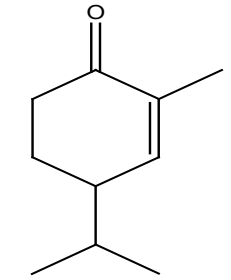

2-methyl-4-(1-methylethyl)2-cyclohexenone

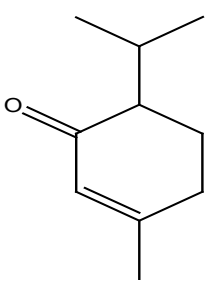

2-cyclohexen-1-one,3-methy 6-(1-methylethyl)-

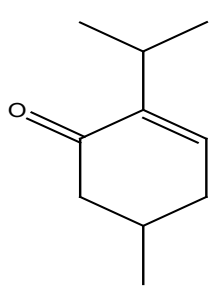

2-cyclohexen-1-one, 5-methyl2-(1-methylethyl)-

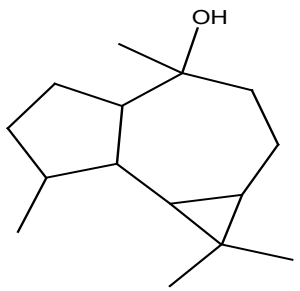

ledol

Figure 1: Chemical structure of the main components of the L.palustre essential oil extract.

In the oil extracts of the aerial parts of the wild L.palustre L. in Daxing'anling area, the major compounds were: $\alpha$-thujenal $(22.48 \% \pm 1.93 \%)$,

bicyclo[3.1.0] hex-3-en-2-one, 5-(1-methylethyl)- (10.37\% \pm $0.81 \%$ ),

$\beta$-phellandrene $(10.25 \% \pm 0.78 \%)$,

benzene, 1 -methyl-3-(1-methylethyl)- $(6.59 \% \pm 0.51 \%)$,

propanal,2-methyl-3-phenyl- $(4.01 \% \pm 0.32 \%)$,

bicyclo[3.1.0] hexan-2-one,5-(1-methylethyl)- $(3.66 \% \pm 0.23 \%)$, $\beta$-terpineol $(3.04 \% \pm 0.20 \%)$,

$1 \mathrm{H}$-cycloprop[e]azulene, decahydro-1,1,7-trimethyl-4-methylene- $(2.96 \% \pm 0.92 \%)$, and

cyclohexanol, 1-methyl-4-(1-methylethenyl)- $(2.50 \% \pm 0.70 \%)$.

Interesting finding is that only $0.19 \% \pm 0.01 \%$ ledol was found in the aerial parts of wild L.palustre L. from north-eastern China when compared with the oil from L.palustre L. from Estonia which contained a high amount of ledol $(11.8 \% \pm 0.87 \%)$ ${ }^{[17]}$. There were considerable differences in composition between them. The antibacterial activity of the extract was tested against the marine pathogen $V$. parahaemolyticus. Only a few bacterial colonies were observed in the extract (Figure. 2). Record the actual number of colonies found and a low concentration of extract $(5 \mathrm{~g} / \mathrm{L})$ can exhibit a good antibacterial activity against $V$. parahaemolyticus (Table 2).

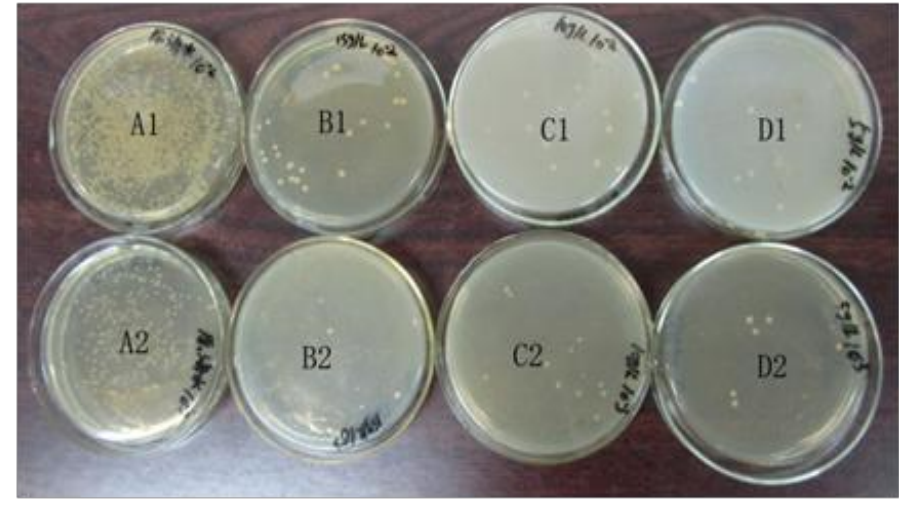

Figure 2: Bacterial sensitivity test of L.palustre essential oil extract against the marine pathogen $V$. parahaemolyticus. (A1, seawater $\times 10^{-2}$; $\mathrm{A} 2$, seawater $\times 10^{-3}$; B1, seawater $\times 10^{-2}+15 \mathrm{~g} / \mathrm{L}$ extract; B2, seawater $\times 10^{-3}+15 \mathrm{~g} / \mathrm{L}$ extract; $\mathrm{C} 1$, seawater $\times 10^{-2}+10 \mathrm{~g} / \mathrm{L}$ extract; $\mathrm{C} 2$, seawater $\times 10^{-3}+10 \mathrm{~g} / \mathrm{L}$ extract; D1, seawater $\times 10^{-2}+5 \mathrm{~g} / \mathrm{L}$ extract; D2, seawater $\times 10^{-3}+5 \mathrm{~g} / \mathrm{L}$ extract).

Table 2: Antibacterial activity of extract of $L$. palustre against the pathogen $V$. parahaemolyticus.

\begin{tabular}{|l|c|c|c|}
\hline \multirow{2}{*}{ Samples } & \multicolumn{3}{|c|}{ Diluted seawater } \\
\cline { 2 - 4 } & $\mathbf{1 0}^{-1}$ & $\mathbf{1 0}^{-\mathbf{2}}$ & $\mathbf{1 0}^{-3}$ \\
\hline $\begin{array}{l}\text { Sterilized sea- } \\
\text { water (Control) }\end{array}$ & $* *$ & $* *$ & $500 \pm 63.2$ \\
\hline $\mathbf{5}$ g/L (T1) & $* *$ & $12.7 \pm 2.5$ & $5.3 \pm 0.6$ \\
\hline $\mathbf{1 0}$ g/L (T2) & $* *$ & $15.3 \pm 0.6$ & $11.7 \pm 1.5$ \\
\hline $\mathbf{1 5}$ g/L (T3) & $* *$ & $19.7 \pm 1.5$ & $8.0 \pm 1.0$ \\
\hline
\end{tabular}

Key:** means $>2000$ colony-forming units. Data expressed as means $\pm \mathrm{SD}(\mathrm{n}=3)$.

The essential oil extract investigated contained high amounts of bicycle compounds:

bicyclo[3.1.0]hex-3-en-2-one, 5-(1-methylethyl)-(10.37\% $\quad \pm$ $0.81 \%$ ),

bicyclo[3.1.0]hexan-2-one,5-(1-methylethyl)-(3.66\% $\pm 0.23 \%)$, bicyclo[3.1.1] hept-2-ene-2-carboxaldehyde,6,6-dimethyl-(1.7\% $\pm 0.11 \%$,

bicyclo[3.1.1]heptan-3-ol,6,6-dimethyl-2-methylene-(1.08\% \pm $0.08 \%$ ),

bicyclo[3.1.0]hexane,4-methyl-1-(1-methylethyl)-(0.98\% $\quad \pm$ $0.08 \%$ ), and

bicyclo[3.1.0]hex-2-ene,2-methyl-5-(1-methylethyl)- $(0.93 \% \pm$ $0.07 \%$ ). In the essential oil from the shoots, leaves and stems of Estonian marsh tea, all the oils investigated contained oxygenated monoterpenes of furyl structure $(0.6 \%-3.8 \%)$, but these compounds were not found to be present in the L.palustre oils investigated in this study ${ }^{[17]}$. A comparison of the oils of L.palustre from north-eastern China with those from various regions of Siberia showed their compositions to differ ${ }^{[2]}$. The oils from 
Russian L.palustre contained high amounts of sabinene $(0.2 \%$ $33.2 \%)$ and limonene $(0.9 \%-50.3 \%)$. The content of ledol and palustrol of the oils was also low $(0-3.9 \%)$. The essential oil extract from the aerial parts of the wild L.palustre from north-eastern China comprised mainly monoterpenes (63.79\%), followed by sesquiterpenes $(4.45 \%)$.

\section{Conclusion}

The yield of essential oil extract from the aerial parts of L.palustre from north-eastern China was $5.31 \% \pm 0.43 \%$ by the sub-critical fluid extraction technology. A total of 56 constituents, accounting for over $89 \%$ of the total oil yield, were identified in the essential oil extract. $\alpha$-Thujenal $(22.48 \% \pm 1.93 \%)$ was the major compound in the oil extract of L.palustre. The total content of bicycle compounds of the samples investigated was $18.72 \%$. The content of ledol of the essential oil extract was $0.19 \% \pm 0.01 \%$. The result of bacterial sensitivity test showed that the L.palustre extract expressed good antibacterial activity against the marine pathogen $V$. parahaemolyticus.

Funding: This work was financially supported by Key Lab. of Biomass Energy and Material, Jiangsu Province (KLBEM) (JSBEM-S-201707) and the National Natural Science Foundation of China (No. 31500485) and the China Basic Research Foundation of National Commonweal Research Institute, CAF (CAFYBB2016QB013).

\section{References}

1. Kim, D., Nam, B. Extracts and essential oil of $L$ palustre L. and their antioxidant and antimicrobial activities.(2006) J Food SciNutr11(2): 100-104.

2. Belousova, N.I., Khan, V.A., Berezovskaya, T.P. Intraspecies chemical variability of the essential oil of Ledum palustre. (1990) Chem Nat Compd 26(4): 398-405.

3. Butkiene, R., Sakociute, V., Latvenaite, D., et al. Composition of young and aged shoot essential oils of the wild Ledum palustre L.(2008) Chimija 19(2): 19-24.

4. Evstratova, R.I., Kabanov, V.S., Krylova, I.L., et al. Content of essential oil and of ledol in leaves of marsh rosemary (Ledum palustre L.) during different phases of vegetation. (1978) Pharm Chem J 12(11): 1468-1473.

5. Mikhailova, N.S., Rybalko, K.S. Chemical constitution of Ledum palustre. (1980) Chem Nat Compd 16: 131-135.

6. Judzentiene, A., Budiene, J., Misiunas, A., et al. Variation in essential oil composition of Rhododendron tomentosum gathered in limited population (in Eastern Lithuania). (2012) Chemija 23(2): 131-135.

7. Kir'Yalov, N.P. Principal Components of the essential oil of Ledum palustre. (1948) DAN SSSR61: 305-308.

8. Mikhailova, N.S., Konovalova, O.A., Zakharov, P.I., et al. Isolation of cyclocolorenone from the essential oil of Ledum palustre. (1978) Chem Nat Compd 14(2): 173-175.

9. Hawthorne, S.B., Grabanski, C.B., Martin, E., et al. Comparisons of Soxhlet extraction, pressurized liquid extraction, supercritical fluid extraction and subcritical water extraction for environmental solids: recovery, selectivity and effects on sample matrix. (2000) J Chromatogr A 892(1-2): 421-433.

10. Herrero, M., Cifuentes, A., Ibañez, E. Sub- and supercritical fluid extraction of functional ingredients from different natural sources: plants, food-by-products, algae and microalgae: a review. (2006) Food Chem 98(1): 136-148.

11. Liu, Z., Mei, L., Wang, Q., et al. Optimization of subcritical fluid extraction of seed oil from Nitraria tangutorum using response surface methodology. (2014) LWT - Food Sci Technol 56(1): 168-174.

12. Daniels, N.A., MacKinnon, L., Bishop, R., et al. L. Vibrio parahaemolyticus infection in the United States, 1973-1998. (2000) J Infect Dis 181(5):1661-1666.

13. Marano, N.N., Daniels, N.A., Easton, A.N., et al. A survey of stool culturing practices for Vibrio species at clinical laboratories in Gulf Coast states. (2000) J Clin Microbiol 38(6): 2267-2270.

14. Mith, H., Dure, R., Delcehserie, V., et al. Antimicrobial activities of commercial essential oils and their components against food - borne pathogens and food spoilage bacteria. (2014) Food Sci Nutr 2(4): 403416.

15. Yano, Y., Satomi, M., Oikawa, H. Antimicrobial effect of spices and herbs on Vibrio parahaemolyticus. (2006) Int J Food Microbiol 111(1): 6-11.

16. Wilkinson, S., Ladd, P. The Use of a Solids Inlet System to Identify Essential Oils in Anthers and Leaves of Flowering Plants. Varian GC/ MS Application Note 65.

17. Gretsusnikova,T., Jarvan, K., Orav, A., et al. Comparative analysis of the composition of the essential oil from the shoots, leaves and stems the wild Ledum palustre L. From Estonia. (2010) Procedia Chem 2(1):168-173.
Online ISSN: 2377-0619

Journal Title: International Journal Food and Nutritional Science Journal Short Name: Int J Food Nutr Sci
Ommega Online Publishers

E-mail: editor.foodscience@ommegaonline.com Website: www.ommegaonline.org 